NOTE: This is the preprint version of a paper already published in The Journal of Academic

Librarianship, Volume 45, Issue 1, January 2019, Pages 9-14.

See final paper here: https://doi.org/10.1016/j.acalib.2018.11.001

\title{
Challenge of Ukrainian Academic Librarians in an Evolving Scholarly Publishing Landscape
}

\section{Serhii Nazarovets ${ }^{1}$, Jaime A. Teixeira da Silva ${ }^{2}$, Maryna Nazarovets ${ }^{3}$}

\author{
${ }^{1}$ State Scientific-Technical Library of Ukraine, 180 Antonovich Street, Kyiv, 03680, Ukraine; \\ serhii.nazarovets@gmail.com
}

${ }^{2}$ Independent researcher, P. O. Box 7, Miki-cho post office, Ikenobe 3011-2, Kagawa-ken, 761-0799, Japan; jaimetex@yahoo.com

${ }^{3}$ Maksymovych Scientific Library, Taras Shevchenko National University of Kyiv, 58 Volodymyrska Street, Kyiv, 01601, Ukraine; marinanazarovets@gmail.com

\begin{abstract}
Faced with a prolonged economic crisis, Ukrainian research institutes are under pressure as a direct result of limited funding. This has also had a negative impact on the functionality of librarians who have seen limitations in acquisitions. Despite the economic difficulties, Ukrainian academic librarians are trying to offer their users specialized services that involve active librarian mediation in the process of preparing and disseminating the results of scientific work of users, in particular in the detection and struggle with pseudoscientific journals. In this paper, based on a survey of librarians from leading Ukrainian universities, we studied for the first time, the main information resources and tools used by Ukrainian experts to test scientific journals for their further recommendation to library users as reliable channels for disseminating research results. These are tools and resources such as Scopus, Web of Science, Beall's black lists, the DOAJ, Think. Check Submit, and The Norwegian Register. We describe the benefits and limitations that may arise in the work of Ukrainian academic librarians when each of the identified resources is used. Modern times of reformation in Ukrainian science has opened up new opportunities for Ukrainian academic librarians. As a result, if they are able to successfully implement such services, they can regain a prominent place in the scientific life of institutions and on the global academic platform.
\end{abstract}


Keywords: Ukrainian academic librarians, academic libraries, predatory journals, scholarly publishing, library services

Editorial note: all three authors are equal contributors and co-corresponding authors.

\section{Introduction and background}

\section{Economic and personal challenges for libraries in Ukraine}

Academic libraries in Ukraine were unprepared for rapid changes which started in scientific communication at the end of the last century. After Ukraine liberated itself from the ideology of totalitarianism and gained independence in 1991, Ukrainian librarians gained an opportunity to develop a national library system. However, in the 1990s, Ukraine's economy entered a long period of hyperinflation, with the highest inflation rate among countries that are not in a state of war, and with prices in Ukraine rising more than $10,000 \%$ per year in that period (Zholud, 2015). Under this economic crisis, it was extremely difficult to reform the national system of education and science, and Ukrainian libraries did not receive adequate funding, equipment or working conditions that would allow them to operate effectively.

The Ukrainian network of libraries has over 39,000 libraries of various types, including libraries of higher educational institutions, technical, agricultural, medical, academic, public libraries for adults, youth, and children, and libraries for the visually impaired (Online Computer Library Center, 2018). The main, and in most cases, only source of funding for all these libraries is the state budget. Throughout the years of independence, Ukrainian libraries were poorly funded, most of the budget was spent on salaries and utilities, and very scarce amounts were allocated to fill the collections of libraries, even in the years of relative stability of the national currency, the hryvnia (Fig. 1). It should be noted that the salary of librarians in Ukraine has concistently not exceeded the minimum wage, which is about $\$ 144$ in 2018 (Trading Economics, 2018). It is clear that the funds allocated by the state were insufficient to provide high-quality information services, in particular, access to the scientific resources of leading publishing houses, which even the library systems of developed countries refused to subscribe to due to their high cost (Vogel, 2016).

In addition to economic opportunities, in the early 1990s, Ukrainian libraries also lacked the intellectual and human resources for wide-scale reform and the introduction of technological innovations. Most of the leaders of different levels, who at that time worked in Ukrainian libraries, were pupils of the Soviet system 
of library education, which was based primarily on the humanities — history, literature and Marxist-Leninist philosophy (Haigh, 2009). Therefore, whereas information and computer technologies in developed countries were effectively implemented into the work of libraries, in Ukraine, by contrast, the gap between the competencies of library staff and the real needs of users increased rapidly: the introduction of automated library systems, online catalogs, provision of online access to prepaid electronic resources, as well as the digitization of library collections occurred inconsistently. For example, the absolute majority of Ukrainian libraries (99.27\%) as of 2007 were not represented on the internet at all, despite the fact that at that time, the number of Internet users in Ukraine was 8 million (Solovianenko, 2007).

In the early 2000s, employees of Ukrainian libraries rethought and appreciated the leading role of computer technology in meeting the information needs of users, and since then, they have been trying to correct the mistakes of their predecessors and make significant efforts to implement services that meet the needs of an information-oriented society (Benz, 2009). However, the limited funding of libraries and, as a result, the extremely limited subscription of information resources, leaves little chance that Ukrainian libraries will soon be able to restore their prominent place as a provider of information services. In addition, today Ukraine is once again in a state of economic and political instability where there is no true free and fair democracy in the country, where highest ranking Ukrainian government officials are regularly accused of corruption, and the country itself opposes the large-scale military aggression of Russia that has lasted since 2014. This indicates that the situation with the financial support of libraries will not change significantly for the better in the near future (Hladchenko, de Boer \& Westerheijden, 2016).

\section{New services for users of academic libraries}

Despite economic and political hardships, librarians are trying to carry out their educational mission, as envisaged in the Law of Ukraine "On Libraries and Library Affairs", in a bid to satisfy the information, research, educational and cultural needs of citizens (Verkhovna Rada of Ukraine, 1995, No 32/95-BP). In particular, employees of Ukrainian academic libraries establish specialized services for their users, while trying to compensate for the lack of adequate funding and access to information resources, by the enthusiasm and constant development of their professional skills.

In the early 2000s, Ukrainian academic libraries offered a typical set of online services, such as remote access to library information resources, or online counselling via email. However, very quickly, Ukrainian academic libraries began to apply a personalized approach to the provision of services that involves intensive 
librarian-user collaboration. This service involves the active mediation of a librarian in the process of preparing and disseminating the research results of users, in particular searching for literature on the topic, explanation of the basic concepts of bibliometrics and scientometrics, assistance in bibliographic management, selection of optimal journals for publication, assistance in placing preprints, developing a policy of storage and distribution data, and advice on using Science 2.0 tools. Around the world, this library service model is often referred to as "Embedded Librarian" ( $\mathrm{Wu} \& \mathrm{Mi}, 2013)$. However, this term is rarely used in Ukraine, and preference is given to the term "Specialist in Support of Scientific Research". Ukrainian librarians work predominantly with postgraduate students and scientists since undergraduate students are rarely involved in research work during their learning process, and therefore their information needs are often limited to selecting materials for courses.

The emergence and popularity of this library service was largely due to the state of science in Ukraine, in particular in social and humanitarian sciences. The long economic crisis in Ukraine has caused serious damage to Ukrainian science, which has led to a brain drain from the country, ageing and lack of research equipment, and an increase in the average age of workers of Ukrainian scientific institutions (DirectorateGeneral for Research and Innovation, European Commission, 2017, p. 29-30). Repeatedly, ambitious goals were set for the development of a national scientific system, but on-going reforms in this research area proved for decades to be rather unsystematic and yielded relatively modest results. The Ukrainian scientific landscape continues to dominate disciplines that were aligned with the needs of the Soviet Union's military economy: physics, chemistry, and engineering (Yegorov, 2009). Social and human sciences could not develop normally under the contnued conditions of Soviet ideology. Accordingly, Ukrainian scholars who work in these fields are deprived of a starting advantage compared to their Ukrainian colleagues in natural sciences, and it is much more difficult for them to integrate into the global scientific space. For example, most Ukrainian journals in these disciplines do not have a well-defined subject area, and, accordingly, are unable to perform their function and to serve as reliable channels of science communication (Kavunenko, Khorevin \& Luzan, 2006). At the same time, it is difficult for Ukrainian authors to fulfil the quality requirements of leading international scientific journals, as they are accustomed to publishing in Ukrainian journals. This has increased their isolation and slowed down the development of social and humanitarian research in Ukraine.

The recent reform initiatives of the Ministry of Education and Science of Ukraine also raised the interest of library users in the Embedded Librarian service. Applicants for the academic rank of professor or 
associate professor in Ukraine should have publications in periodicals included in Scopus or Web of Science (WoS) databases (Ministry of Education and Science of Ukraine, 2016, No 13), and applicants for a PhD degree must have publications "in scientific periodicals of other countries" (Ministry of Education and Science Youth and Sports of Ukraine, 2012, No 1112). It is clear that such a requirement of publication, regardless of the quality of foreign journals, is meaningless and incapable of improving the presentation of Ukrainian scientists (Nazarovets \& Nazarovets, 2018). However, despite criticisms and suggestions of and by the Ukrainian scientific community, officials of the Ministry of Education and Science of Ukraine left the text of the wording of this law unchanged, once again demonstrating the inconsistency of Ukrainian reforms.

Most Ukrainian scientists, especially in the social sciences and humanities, who have faced this publishing requirement for articles in journals indexed in Scopus or WoS, are forced to open a world of modern scientific communication in novel ways. They sought assistance from librarians who, within the broader service of an Embedded Librarian, help scientists to deal with new issues to them: the use of specialized tools for scientists, international bibliographic styles, copyright issues, self-archiving of preprints, and, in particular, the selection of a reliable journal for publication.

In addition to scientists, heads of Ukrainian higher education institutions are also interested in library services for the selection of high-quality scientific journals for the publication of research results. The level of funding for higher education institutions in Ukraine depends primarily on the number of students: students studying at the expense of a government order and whose tuition is paid by the state, and students who study on a commercial basis and independently pay their tuition. In 2016, 1,369,400 students studying in 287 Ukrainian universities (excluding educational institutions of the temporarily occupied territory of the Autonomous Republic of Crimea, Sevastopol and parts of the territory in the East of Ukraine captured by pro-Russian militants) (State Statistics Service of Ukraine, 2017), of these, approximately 64,000 are foreign students (Ukrainian State Center for International Education, 2017). The number of Ukrainians who favour the acquisition of higher education abroad, especially in neighbouring Poland, increased significantly. The growth in the number of Ukrainians studying in foreign universities from 2009 to 2015 swelled to $129 \%$ (Slobodian \& Stadny, 2016). Accordingly, there is very strong competition between Ukrainian universities for obtaining entrants.

In order to attract entrants, the leaders of Ukrainian universities are trying to demonstrate that their institutions are integrated into international science. As a rule, data from international university ratings, such as The Times Higher Education World University Rankings (in 2018, only 19 universities are from the 
Ukraine (Times Higher Education, 2017, February 16), and only 5 of them are in the top 1,000 universities in the world (Times Higher Education, 2017, August 18)), is used for this purpose. According to the methodology of calculation (Times Higher Education, 2017, August 29), a high rating, or even the very ability to enter a ranked university, depends on the publication activity of employees of that institution. Therefore, heads of Ukrainian universities are interested in publishing papers in quality journals, which will improve the representation of their university in these ratings and make it more attractive for entrants.

In addition to the reputational advantages, the publication activity of employees can bring a university significant financial benefits. The number of publications of scientists of an institution in journals indexed "in the scientometrics bases Scopus, Web of Science, other scientometrics bases recognized by the Ministry of Education and Science of Ukraine" (Cabinet of Ministers of Ukraine, 2017, No 912) is evaluated in order to assign a national status to that institution. The national status significantly increases funding to the institution from the budget of the country compared to institutions that do not have this status (Verkhovna Rada of Ukraine, 2014, July 1).

\section{Threats of the spread of unscholarly or pseudo-scientific journals}

The relative simplicity by which online and/or open access (OA) journals could be created, and the low costs needed to sustain such publication, led, to some extent, the scientific world facing an unprecedentedly large number of journals, some of which were pseudo-scientific, i.e., posing as OA journals, but after receiving a fee (article processing charge, or APC) from authors, quickly publish any material without proper peer review. The results of research of the motivation of authors from developing countries who published research in pseudo-scientific journals suggest that some scientists did not suspect the questionable quality of selected publications. Rather, they simply felt more comfortable in submitting a manuscript to a journal from a developing country than that publishing in a journal from a developed country, not wishing to repeat such a mistake in the future. Despite this risk, some authors admitted that they would continue to publish in similar OA journals if their institution recognized their publications (Kurt, 2018).

Such behaviour of university staff constitutes a serious threat since the publication of pseudo-scientific research may cause enormous damage, not only to the reputation of the scientist but, also to that of their institution while potentially wasting resources, financial or other (Moher et al., 2017). In addition, unscrupulous university staff will be able to report on the successful implementation of scientific research at their institute without proper review of publications and, consequently, receive certain material awards and 
promotions without deserving them. As a result, such incompetent scientists will not be able to solve complex administrative, educational or scientific tasks, and this will inevitably lead to an eventual decline in the quality of the university's scientific work (Ifijeh, 2017; Balehegn, 2017). Therefore, the leadership of an ambitious university, whether in the Ukraine or elsewhere, should be interested in the enlightenment of scientists and conducting information campaigns aimed at preventing the publication of manuscripts in questionable journals, as well as in detecting unscrupulous academics who have succeeded in using unethical manipulations with quantitative indicators to advance their scientific careers.

\section{Problem statement}

To date, there is no defined or formalized verification procedure that would allow pseudo-scientific journals to be quickly or effectively recognized. However, there are several specialized tools that librarians use to complete this task. The aim of this study was to assess the main information resources used by specialists of Ukrainian academic libraries to check scientific journals for recommendation to library users as reliable channels for the distribution of scientific research results. To achieve this goal, we conducted a survey of specialists of academic libraries of leading Ukrainian universities that are engaged in preparing recommendations for choosing journals for authors.

\section{Methodology}

We interviewed librarians from nine leading Ukrainian universities (based on The Times Higher Education World University Rankings): Central Scientific Library of V.N. Karazin Kharkiv National University, G.I. Denysenko Scientific Library of the National Technical University of Ukraine "Igor Sikorsky Kyiv Polytechnic Institute", Library and Information Center of Sumy State University, Maksymovych Scientific Library of Taras Shevchenko National University of Kyiv, National University of Ostroh Academy Library, Scientific and Technical Library of the National Technical University "Kharkiv Polytechnic Institute", Scientific Library of Lviv Polytechnic National University, Scientific Library of Uzhhorod National University, Scientific Library of Yuriy Fedkovych Chernivtsi National University.

We proposed library representatives to answer the following questions:

- Does your institution provide journal selection services for a publication aimed at countering “predatory”, unscholarly or low-quality journals?

- What online resources and/or tools do your employees use to provide such services? 
Based on the responses we received, we compiled a list of the most popular resources used by Ukrainian academic librarians to identify academically suspicious journals and provide appropriate guidance to their university researchers and managers.

\section{Results}

We identifed fve major resources used by Ukrainian academic librarians to identify suspicious journals and to offer guidance to their institutes' academics.

\section{Scopus / Web of Science}

Two commercial resources are the most popular for searching journals for publication among Ukrainian librarians, Scopus (Elsevier) and the WoS Core Collection (Clarivate Analytics). This popularity is due to the use of indicators of these databases by government agencies, as exemplified by the official education ministerial orders we mentioned above. Journals are indexed in Scopus and WoS for free, but full-featured user access to Scopus and WoS platforms requires a subscription. In accordance with the Order of the Ministry of Education and Science of Ukraine, more than 100 Ukrainian universities received the Scopus and/or WoS subscription from the state budget in 2018. Most users of these institutions have access to these products for the first time (Ministry of Education and Science of Ukraine, 2017, No 1286).

Scopus and WoS Core Collection compilers maintain transparent criteria for selecting scientific content (Mongeon \& Paul-Hus, 2016). All journals that submit an application for inclusion in these databases must meet minimum publishing criteria, including compliance with publishing ethical standards, conducting a review of manuscripts, have a registered ISSN, a definite timetable for publication, titles and abstracts of articles in English, etc. (Appendix A, Supplementary file). In addition, independent experts evaluate the editorial policy of the journal, the reputation of its editors, the variety of the geographic distribution of editors and authors, the quality of the web page, the citation of the journal articles and the relevance of published research (Elsevier, 2018).

Despite careful selection, Scopus and WoS Core Collection experts annually suspend the indexing of dozens of journals due to the decline in their scientific quality and violation of publishing standards. At the same time, all articles published in the journal before coverage was discontinued will remain forever in the database even if the journal was excluded due to the publication of doubtful articles. 
Therefore, librarians should pay attention to the actual information on the indexation of the journal in the databases and its indicators that may raise suspicion since the mere fact of having a journal in one of these databases, unfortunately, can not yet testify to its scientific quality. On the other hand, since Scopus and WoS Core Collection contain a limited number of scientific journals, the absence of a journal on these databases also does not necessarily reflect its lac of scientific value.

\section{Beall's black lists}

An American librarian, Jeffrey Beall, created two black lists on his personal blog that he referred to as "potential, possible or probable" predatory OA journals and publishers. He suspected, as one of the criteria for inclusion of these journals and publishers, based primarily on personal accounts and inconclusive evidence, that some of these journals or publishers did not properly vet or peer review manuscripts, but simply served as paper mills to extract APCs from authors and their institutes. Beall (2016) used his own criteria to establish his black lists, whose fairness was sometimes criticized, while their accuracy and legitimacy is now being rigorously scrutinized in a post-publication peer review to evaluate the possible effects Beall and his black lists may have had on the "predatory" publishing literature and on policy (Teixeira da Silva, 2017a, 2017b, 2018a, 2018b). In January 2017, Beall deleted all the information on his site, but copies of his lists and criteria are now available on some other web resources and are still used by Ukrainian librarians to identify questionable OA publishers and journals (Beall, 2015). Ukrainian academics are not punished or penalized in any way if they publish in journals or publishers that appeared on Beall's black lists.

Apart from Actual Problems of Economics, there do not appear to have been any other OA publishers or individual journals that were active only in post-Soviet countries under Beall's radar, therefore his black lists were not useful to Ukrainian librarians, although the presence of a journal or publisher on those lists gives them a certain additional marker that they require a more thorough check.

\section{DOAJ}

The Directory of Open Access Journal (DOAJ) (https://doaj.org) was designed to ease the work of users with scientific and scholarly OA journals, and uses a quality control system in order to guarantee users access to quality content only ( $\mathrm{Bi}, 2017)$. Before adding a journal to its directory, the DOAJ editors pay attention to compliance with publishing standards by journal editors, including the completeness of the 
information about the journal, the quality of its website content, the transparency of the publishing and review process, publication fees, copyright notices (Appendix B, Supplementary file). If any violations of minimum requirements are found, the journal will not be included in the DOAJ until they are resolved. Therefore, the presence of a journal in the directory signals to Ukrainian academic librarians about the compliance with certain publishing standards.

Since the DOAJ only includes OA journals that immediately give users unlimited access to all content, the directory is not suitable for checking journals that do not support OA or that apply embargo policies. In addition, the proposed minimum criteria by which DOAJ editors analyze only the information presented on the journal website are not enough to identify pseudo-scientific journals. It is relatively easy for "predatory" OA journal owners to demonstrate the formal fulfilment of requirements and to detail the necessary information on the website simply to get into the DOAJ directory, but not to adhere to the declared principles. It is possible that this is one reason why journals and publishers are being continually deliested from the DOAJ ${ }^{1}$.

Think. Check. Submit

The initiative of publishers, scholars and librarians "Think. Check. Submit" (http://thinkchecksubmit.org) does not contain a list of names of suspicious journals. Rather, it offers authors a checklist of questionable criteria that will help them decide whether to send your manuscript safely to this journal or publisher (Dobson, 2016). The online tool and proposed criteria are used by Ukrainian librarians mainly for group training and individual counselling for young scientists in search of reliable journals to present their research results (Appendix C, Supplementary file).

\section{The Norwegian Register}

The Norwegian system of financing higher education allocates funding to institutions according to the indicators of their publication activity. The Norwegian Social Science Data Services (NSD) provides an updated list of The Norwegian Register for Scientific Journals, Series and Publishers (https://dbh.nsd.uib.no/publiseringskanaler/Forside), publications that bring financial reward to Norwegian institutions (Appendix D, Supplementary file). The register is available free of charge and is also used in other countries worldwide for the purpose of evaluating the scientific activities of institutions.

\footnotetext{
${ }^{1}$ https://docs.google.com/spreadsheets/d/183mRBRqs2jOyP0qZWXN8dUd02D4vL0Mov_kgYF8HORM/edit\#gid=0
} 
The recently launched Dimensions Scientific Platform (https://www.dimensions.ai) offers users the ability to filter the search results of journals for inclusion in PubMed, DOAJ, Excellence in Research for Australia (ERA), and The Norwegian Register, which can increase the popularity of using the registry around the world. Thus far, there was no information that Ukrainian officials plan to use it at the state level. Therefore, Ukrainian librarians very rarely turn to this resource.

\section{Other solutions}

In addition, librarians from Ukrainian universities indicated that they are sporadically using other information resources, including The Scimago Journal \& Country Rank (http://www.scimagojr.com), which is available free of charge and based on Scopus data.

Academic librarians are not the only ones who are working today in Ukraine to develop an official procedure for checking the validity of scientific journals. For example, criteria for evaluating Ukrainian scientific periodicals were proposed by members of the Scientific Committee of the National Council for Science and Technology Development, which was created under the Cabinet of Ministers of Ukraine. On the basis of these proposals, the "Order of Formation of the List of Scientific Professional Editions of Ukraine" (Ministry of Education and Science of Ukraine, 2018, No 32) was created (Appendix E, Supplementary file). Since it only entered into force at the time of writing this article, we cannot yet explore and evaluate its practical ability to deal with unscrupulous Ukrainian scientific journals

\section{Discussion}

Thus, we managed to describe for the first time the most popular information resources used by specialists of Ukrainian academic libraries to check the quality and/or validity of scientific journals or publishers for recommendation to scientists and Ukrainian academics, in their role as Embedded Librarians, potentially reliable sources for obtaining and disseminating scientific information. Unfortunately, each of these resources has its own disadvantages and/or weaknesses, which do not guarantee protect of the user from cooperation with unscrupulous, "predatory" or unscholarly publishers, OA or not. Therefore, this challenge requires further work, not only by librarians but, of course, also from the academic community, policy makers and government officials.

Times of reform open up new opportunities for Ukrainian academic librarians who can try to regain prominence in the scientific life of their institutions, since ambitious leaders and university scientists who 
seek to develop their institutions and grow their competitiveness must be fully committed to creating and maintaining quality specialized library services, including those aimed at the evaluation of scientific publications and the fight against pseudo-scientific journals. It is necessary that such initiatives be supported by responsible Ukrainian officials. However, the lack of clear requirements for the quality of scientific publications in the official documents of the Ministry of Education and Science of Ukraine, on the contrary, potentially encourages university staff to exaggerate the number and impact of their publication activity. It may distort the actual publication situation of Ukrainian science and does not allow for the creation of an effective plan for its development.

If the efforts of academic activists, including academic librarians, do not find state support, and no logical requirements for the quality of scientific publications will soon be introduced, this will de facto mean legitimization of the publications of university employees in "predatory" or pseudo-scientific journals, and the academic crisis in Ukrainian science will only intensify. Quantitative indicators of publication activity, obtained at the expense of articles in potentially fake academic journals, conceal the real information needs of university employees, first of all, in access to leading scientific content and tools, and training and support of high-quality library specialists. It will lead to "freezing" library budgets. Such "depressed" libraries have hardly any place in the scientific life of an academic university.

\section{Conclusion}

The introduction of state requirements for the quality of scientific publications in Ukraine can significantly improve the demand for quality academic library services, draw attention to library acquisition issues and generally contribute to a rethinking of the role of the library in the system of university science. Of course, this is not the only direction that needs to be taken in the work of academic libraries in Ukraine. However, personnel policy, as well as the content and direction of Ukrainian library services will depend on the effectiveness of the fight against pseudo-science and unscholarly behaviour in the next few years.

\section{Acknowledgements}

The authors thank Andriy Andrukhiv (Scientific Library of Lviv Polytechnic National University), Yuliia Glavcheva (Scientific and technical Library of the National Technical University "Kharkiv Polytechnic Institute"), Iryna Kaplenko (Library and Information Centre of Sumy State University), Yuriy Kotsyuk (National University of Ostroh Academy Library), Yevgeniya Kulyk (G.I. Denysenko Scientific 
Library of the National Technical University of Ukraine "Igor Sikorsky Kyiv Polytechnic Institute"), Maria Medved (Scientific Library of Uzhhorod National University), Oleg Serbin (Maksymovych Scientific Library of National Taras Shevchenko University of Kyiv), Oleg Shylyuk (Scientific Library of Yuriy Fedkovych Chernivtsi National University), Irina Zhuravlyova (Central Scientific Library of V.N. Karazin Kharkiv National University) and all in Ukraine, for their kind feedback to our request for information regarding the resources currently being used officially by libraries throughout.

\section{References}

Balehegn, M. (2017). Increased publication in predatory journals by developing countries' institutions: What it entails? And what can be done? International Information and Library Review, 49(2), 97-100. https://doi.org/10.1080/10572317.2016.1278188

Beall, J. (2015). Criteria for Determining Predatory Open-Access Publishers. Retrieved from http://web.archive.org/web/20170105195017/https://scholarlyoa.files.wordpress.com/2015/01/criteria2015.pdf

Beall, J. (2016). Best practices for scholarly authors in the age of predatory journals. The Annals of The Royal College of Surgeons of England, 98(2), 77-79. https://doi.org/10.1308/rcsann.2016.0056

Benz, S. (2009). Ukrainian libraries of yesterday, today, and tomorrow: Impressions from an American Fulbright librarian. Slavic and East European Information Resources, 10(4), 326-331.

https://doi.org/10.1080/15228880903278322

Bi, X. (2017). Quality open access publishing and registration to Directory of Open Access Journals. Science Editing, 4(1), 3-11. https://doi.org/10.6087/kcse.82

Cabinet of Ministers of Ukraine. (2017, November 22). Resolution On Approval of the Procedure and criteria for the granting of a national educational establishment, confirmation or deprivation of this status (No 912). Retrieved from http://zakon3.rada.gov.ua/laws/show/912-2017-П

Directorate-General for Research and Innovation (European Commission). (2017). Peer review of the Ukrainian research and innovation system: Horizon 2020 policy support facility - Study. https://doi.org/10.2777/095726

Dobson, H. (2016). Think.Check.Submit.: the campaign helping researchers navigate the scholarly communication landscape. Insights the UKSG Journal, 29(3), 228-232. 
Elsevier. (2018). Content Selection and Advisory Board. Retrieved March 8, 2018, from https://www.elsevier.com/solutions/scopus/content/scopus-content-selection-and-advisory-board

Haigh, M. (2009). Two steps forward, one step back: Ideological and historical aspects of library and information science education in independent Ukraine. In W. William, Graves, James M., Nyce, Janine, Golden, Delmus E. (Ed.), Advances in Library Administration and Organization (Advances in Library Administration and Organization, Volume 27) (pp. 1-24). Emerald Group Publishing Limited. https://doi.org/10.1108/S0732-0671(2009)0000027006

Hladchenko, M., de Boer, H. F., \& Westerheijden, D. F. (2016). Establishing research universities in Ukrainian higher education: the incomplete journey of a structural reform. Journal of Higher Education Policy and Management, 38(2), 111-125. https://doi.org/10.1080/1360080X.2016.1150232

Ifijeh, G. (2017). Emergence of predatory publishing in library and information science: Issues and implications for scholarship among academic librarians in Nigeria. Bilgi Dunyasi, 18(1), 149-161. https://doi.org/10.15612/BD.2017.572

Kavunenko, L., Khorevin, V., \& Luzan, K. (2006). Comparative analysis of journals on social sciences and humanities in Ukraine and the world. Scientometrics, 66(1), 123-132. https://doi.org/10.1007/s11192$\underline{006-0009-0}$

Kurt, S. (2018). Why do authors publish in predatory journals? Learned Publishing. https://doi.org/10.1002/leap.1150

Ministry of Education and Science of Ukraine. (2016, January 14). Order On approval of the Procedure for assigning scientific degree to scientific and research workers (No 13). Retrieved from http://zakon2.rada.gov.ua/laws/show/z0183-16/

Ministry of Education and Science of Ukraine. (2017, September 19). Order On granting access to higher education institutions and academic institutions in the management of the Ministry of Education and Science of Ukraine to electronic scientific databases (No 1286). Retrieved from http://old.mon.gov.ua/ua/about-ministry/normative/8079-

Ministry of Education and Science of Ukraine. (2018, January 15). Order On approval of the Procedure for the formation of the List of scientific professional publications of Ukraine (No 32). Retrieved from http://zakon3.rada.gov.ua/laws/show/z0148-18?info=1 
Ministry of Education and Science Youth and Sports of Ukraine. (2012, October 17). Order About publication of the results of dissertations for obtaining scientific degrees of the doctor and candidate of sciences (No 1112). Retrieved from http://zakon2.rada.gov.ua/laws/show/z1851-12

Moher, D., Shamseer, L., Cobey, K.D., Lalu, M.M., Galipeau, J., Avey, M.T., Ahmadzai, N., Alabousi, M., Barbeau, P., Beck, A., Daniel, R., Frank, R., Ghannad, M., Hamel, C., Hersi, M., Hutton, B., Isupov, I., McGrath, T.A., McInnes, M.D.F., Page, M.J., Pratt, M., Pussegoda, K., Shea, B., Srivastava, A., Stevens, A., Thavorn, K., van Katwyk, S., Ward, R., Wolfe, D., Yazdi, F., Yu, A.M., Ziai, H. (2017). Stop this waste of people, animals and money. Nature 549(7670): 23-25. https://doi.org/10.1038/549023a

Mongeon, P., \& Paul-Hus, A. (2016). The journal coverage of Web of Science and Scopus: a comparative analysis. Scientometrics, 106(1), 213-228. https://doi.org/10.1007/s11192-015-1765-5

Nazarovets, S., Nazarovets, M., 2018. Local journals and misleading metrics: A quantitative analysis of publication activity of LIS postgraduate students in Ukraine. Bilgi Dünyasi. https://doi.org/10.15612/bd.2018.643

Online Computer Library Center. (2018). Global Library Statistics. Retrieved March 8, 2018, from https://www.oclc.org/en/global-library-statistics.html

Slobodian, O., \& Stadny, Y. (2016). Ukrainian students abroad: how many and why? CEDOS. Retrieved from https://cedos.org.ua/en/osvita/ukrainski-studenty-za-kordonom-skilky-ta-chomu\#

Solovianenko, D. (2007). Statistics on the use of Internet technologies in libraries in Ukraine. Bibliotechnyi Visnyk, 1, 6-19. Retrieved from http://dspace.nbuv.gov.ua/handle/123456789/334

State Statistics Service of Ukraine. (2017). Higher education institutions. Retrieved March 8, 2018, from http://www.ukrstat.gov.ua/operativ/operativ2005/osv_rik/osv_u/vuz_u.html

Teixeira da Silva, J.A. (2017a). Caution with the continued use of Jeffrey Beall's “predatory" open access publishing lists. AME Medical Journal 2: 97. https://doi.org/10.21037/amj.2017.06.14

Teixeira da Silva, J.A. (2017b) Jeffrey Beall's "predatory" lists must not be used: they are biased, flawed, opaque and inaccurate. Bibliothecae.it 6(1): 425-436. https://doi.org/10.6092/issn.2283-9364/7044

Teixeira da Silva, J.A. (2018a). The illicit and illegitimate continued use of Jeffrey Beall's "predatory" open access black lists. Journal of Radical Librarianship 4: 1-5. 
Teixeira da Silva, J.A. (2018b) The ethical and academic implications of the Jeffrey Beall (www.scholarlyoa.com) blog shutdown. Science and Engineering Ethics (in press). https://doi.org/10.1007/s11948-017-9905-3

Times Higher Education. (2017, August 18). World University Rankings 2018. Retrieved April 11.2018, from https://www.timeshighereducation.com/world-university-rankings/2018/world-ranking

Times Higher Education. (2017, August 29). World University Rankings 2018 methodology. Retrieved April 11.2018, from https://www.timeshighereducation.com/world-university-rankings/methodology-worlduniversity-rankings-2018

Times Higher Education. (2017, February 16). Study in Ukraine. Retrieved April 11.2018, from https://www.timeshighereducation.com/student/where-to-study/study-in-ukraine

Trading Economics. (2018). Ukraine Minimum Wages. Retrieved April 11.2018, from https://tradingeconomics.com/ukraine/minimum-wages

Ukrainian State Center for International Education. (2017). International students in Ukraine. Retrieved March 8, 2018, from http://studyinukraine.gov.ua/life-in-ukraine/international-students-in-ukraine/

Verkhovna Rada of Ukraine. (2014, July 1).Law of Ukraine On Higher Education (No 1556-VII). Retrieved from http://zakon3.rada.gov.ua/laws/show/1556-18/

Verkhovna Rada of Ukraine. (1995, January 27). Law of Ukraine On libraries and librarianship (No 32/95BP). Retrieved from http://zakon3.rada.gov.ua/laws/show/32/95-вp

Vogel, G. (2016, December 22). Thousands of German researchers set to lose access to Elsevier journals. Science. https://doi.org/10.1126/science.aal0552

Wu, L., \& Mi, M. (2013). Sustaining librarian vitality: Embedded librarianship model for health sciences libraries. Medical Reference Services Quarterly, 32(3), 257-265. https://doi.org/10.1080/02763869.2013.806860

Yegorov, I. (2009). Post-Soviet science: Difficulties in the transformation of the R\&D systems in Russia and Ukraine. Research Policy, 38(4), 600-609. https://doi.org/10.1016/J.RESPOL.2009.01.010

Zholud, O. (2015). Inflation in Ukraine: past, present and future. Retrieved March 8, 2018, from https://voxukraine.org/en/inflation-in-ukraine-past-present-and-future/ 
Fig. 1. Use of annual funds (USD) by libraries in the sphere of management and influence of the Ministry of Culture of Ukraine in 1999-2016*. Data was obtained from the statistical digest "Library Ukraine in numbers" (https://goo.gl/VomH2j). The conversion hryvnia into USD was based on the official exchange rate at the end of each year.

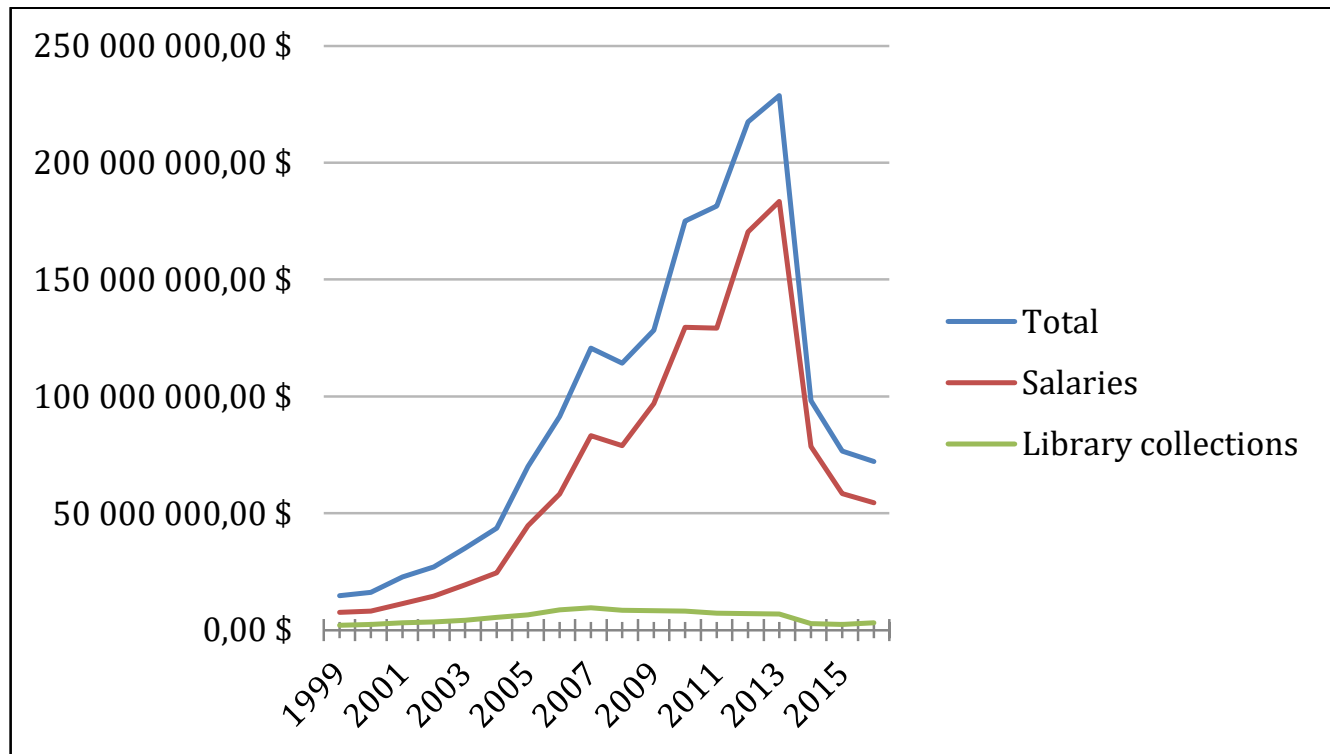




\begin{tabular}{|c|c|}
\hline Scop & 0 \\
\hline $\begin{array}{l}\text { Journal Policy: } \\
\text { - Convincing editorial policy } \\
\text { - } \text { Type of peer review } \\
\text { - } \text { editors } \\
\text { Diversity in geographical distribution of } \\
\text { authors } \\
\text { Content: } \\
\text { - Academic contribution to the field } \\
\text { - Clarity of abstracts } \\
\text { - Quality of and conformity to the stated aims } \\
\text { - Readability of articles } \\
\text { Journal Standing: } \\
\text { - Citedness of journal articles in Scopus } \\
\text { - Editor standing } \\
\text { Publishing Regularity: } \\
\text { - No delays or interruptions in the publication } \\
\text { Online Availability: } \\
\text { - Full journal content available online } \\
\text { - English language journal home page } \\
\text { - available } \\
\text { Quality of journal home page }\end{array}$ & $\begin{array}{l}\text { Basic publishing standards: } \\
\text { - Peer Review } \\
\text { - } \text { Acknowledgements } \\
\text { - } \text { Publishing Format } \\
\text { - Timeliness } \\
\text { - International Editorial Conventions } \\
\text { - Full Text English } \\
\text { Editorial content: } \\
\text { - The content of a journal under evaluation } \\
\text { will enrich the database } \\
\text { International focus: } \\
\text { - International diversity among the journal's } \\
\text { contributing authors, editors, and editorial } \\
\text { advisory board members }\end{array}$ \\
\hline
\end{tabular}

\footnotetext{
* https://www.elsevier.com/solutions/scopus/content/content-policy-and-selection
}

** https://clarivate.com/essays/journal-selection-process/ 


\section{Appendix B. Basic requirements for inclusion in Directory of Open Access Journals (DOAJ)*}

- The full text of ALL content must be available for free and be Open Access without delay without embargo period;

- The journal has its own dedicated website. No other service or product should be present under that URL. All the journal content that the publisher is including in the application must be in one place and not spread over various locations;

- All the necessary journal business information pages must be hosted on this same site and not be held centrally on another web site, or must be prominently linked to from the journal's homepage;

- Every article of journal must have a unique URL;

- A journal must have at least one ISSN registered at issn.org;

- A journal's homepage must contain clear navigation with links to a Current Issue, the Archive or Past Issues, Search, Browse, the About page, the Editorial Board and Contact Us;

- A link to the Editorial Board must be displayed prominently on the journal's home page. The following information must be made available on the Editorial Board page: the name and affiliation of the editorial board members. The page must be up-to-date;

- All articles must go through a quality control system (editorial or peer review) before publication and the exact type of review must be stated clearly on the web site;

- A link to detailed and comprehensive guidelines for authors (Instructions for Authors) must be clearly presented on the journal's homepage;

- Every journal must display clearly on its web site information about any charges for an author to process or publish a paper;

- The journal's Open Access policy must be clearly stated on the journal's web;

- In all instances the journal web site must state clearly and precisely the terms of use and reuse that readers and authors have when they submit an article or use the published content.

* https://doaj.org/publishers\#advice (last accessed: April 10, 2018) 


\section{Appendix C. «Think. Check. Submit» check list to assess the journal*}

- Do you or your colleagues know the journal?

- Have you read any articles in the journal before?

- Is it easy to discover the latest papers in the journal?

- Can you easily identify and contact the publisher?

- Is the publisher name clearly displayed on the journal website?

- Can you contact the publisher by telephone, email, and post?

- Is the journal clear about the type of peer review it uses?

- Are articles indexed in services that you use?

- Is it clear what fees will be charged?

- Does the journal site explain what these fees are for and when they will be charged?

- Do you recognise the editorial board?

- Have you heard of the editorial board members?

- Do the editorial board mention the journal on their own websites?

- Is the publisher a member of a recognized industry initiative?

- Do they belong to the Committee on Publication Ethics (COPE)?

- If the journal is open access, is it listed in the Directory of Open Access Journals (DOAJ)?

- If the journal is open access, does the publisher belong to the Open Access Scholarly Publishers' Association (OASPA)?

- Is the journal hosted on one of INASP's Journals Online platforms (for journals published in Bangladesh, Nepal, Sri Lanka, Central America and Mongolia) or on African Journals Online (AJOL, for African journals)?

- Is the publisher a member of another trade association?

* https://thinkchecksubmit.org/check/ (last accessed: April 10, 2018) 


\section{Appendix D. Criteria for inclusion of new scientific publication channels in the Norwegian Register for Scientific Journals, Series and Publishers*}

1. Established procedures for external peer review. The concept of external peer review refers to various forms of editorial procedures that differ between academic fields and publication channels, and which indicate that the manuscript has been evaluated by one or more independent experts on the subject matter. 2. An academic editorial board (or an equivalent) primarily consisting of researchers from universities, research institutes etc.

3. International or national authorship.

Authorship of a publication channel is defined in accordance with the following operational criteria:

- Authorship is international when less than two-thirds of the authors published in the publication channel are from the same country;

- Authorship is national when more than two-thirds of the authors published in the publication channel are from the same country;

- Authorship is local when more than two-thirds of the authors published in the publication channel are from the same institution.

* https://dbh.nsd.uib.no/publiseringskanaler/OmKriterier.action (last accessed: April 10, 2018) 


\begin{tabular}{|c|c|}
\hline $\begin{array}{l}\text { Category A } \\
\text { (Категорія “A”) }\end{array}$ & $\begin{array}{l}\text { Scientific periodicals of Ukraine, which are indexed by Scopus and/or Web of } \\
\text { Science Core Collection. }\end{array}$ \\
\hline $\begin{array}{l}\text { Category B } \\
\text { (Категорія “Б”) }\end{array}$ & $\begin{array}{l}\text { Journals that meet the requirements of items 1-8: } \\
\text { 1) a certificate of state registration of mass media with the national and/or } \\
\text { foreign sphere of distribution (for periodical printed scientific } \\
\text { publications); } \\
\text { 2) ISSN which is used to identify the printed and/or electronic periodicals } \\
\text { and compliance with the stated periodicity; } \\
\text { 3) assigning to each published paper of the international digital identifier DOI } \\
\text { (Digital Object Identifier); } \\
\text { 4) a web-site of the journal with Ukrainian and English interfaces (an } \\
\text { interface may have other foreign languages related to the area of } \\
\text { distribution of the journal) or web-pages of the journal on the website of } \\
\text { the founder (co-founder) with such information: } \\
\text { a) policy (purpose and objectives) of the scientific publication; } \\
\text { b) the structure of the editorial board, indicating the degree, rank and } \\
\text { main place of work; } \\
\text { c) peer review procedure and adherence to ethical standards in } \\
\text { publishing; } \\
\text { d) the procedure for preparing and submitting the manuscript for } \\
\text { publication; } \\
\text { e) information on the conditions of access and annotation to each } \\
\text { article in accordance with the content of the issues published on } \\
\text { the web-page of the journal; } \\
\text { f) if the journal is not completely English-speaking, each non- } \\
\text { English article is accompanied by an annotation in English of at } \\
\text { least } 1800 \text { characters, including keywords; if the journal is not } \\
\text { completely Ukrainian-speaking, each non-Ukrainian article is } \\
\text { accompanied by an annotation in Ukrainian of at least } 1800 \\
\text { characters, including keywords; } \\
\text { scientists who have a degree in one of the specialties that correspond to the } \\
\text { scientific profile of the journal; each of these specialists, including the } \\
\text { editor-in-chief, must have at least three publications in the last five years } \\
\text { or at least seven publications (articles, monographs, sections of } \\
\text { monographs corresponding to the scientific profile of the journal) for the } \\
\text { last fifteen years (in that including at least one in the past three years), } \\
\text { published in at least two different journals included in the Web of Science }\end{array}$ \\
\hline
\end{tabular}




\begin{tabular}{|l|l|}
\hline & $\begin{array}{c}\text { Core Collection and/or Scopus, or have monographs or sections of } \\
\text { monographs issued by international publishers belonging to the categories } \\
\text { "A", "B" or "C" according to SENSE classification; the editorial board } \\
\text { should include at least three scientists working in Ukrainian academic } \\
\text { institutions or institutions of higher education, and at least one scientist } \\
\text { working in a foreign academic institution or institution of higher } \\
\text { education; a scientist may be a member of not more than three editorial } \\
\text { boards of journals included in the List; } \\
\text { inclusion in the "profile international scientometrics databases } \\
\text { recommended by the Ministry of Education and Science". }\end{array}$ \\
\hline $\begin{array}{l}\text { Category C } \\
\text { (Kaтегорія "B") }\end{array}$ & $\begin{array}{l}\text { Journals that meet the requirements of items 1-5 of the Category B (KaTeropiя } \\
\text { "Б"). Category C is assigned to all scientific professional journals included in the } \\
\text { List on the day of the approval of the Order by the Ministry of Education and } \\
\text { Science, and journals that were excluded from Category A or B are added to the } \\
\text { Category C for two years. Category C journal, which did not get the Category A or } \\
\text { B for two years, is excluded from the List without the right to renew. }\end{array}$ \\
\hline
\end{tabular}

* http://zakon3.rada.gov.ua/laws/show/z0148-18?info=1 (last accessed: April 10, 2018) 